\title{
ras and p53 in the prediction of survival in Dukes' stage B colorectal carcinoma
}

\author{
M A Bennett, E W Kay, H Mulcahy, L O'Flaherty, D P O'Donoghue, M Leader, \\ D T Croke
}

\begin{abstract}
Aims-To determine possible associations between $p 53$ allelic deletion, c-Ki-ras mutational activation, immunohistochemical detection of p53 and ras proteins, various clinicopathological variables, and patient outcome in 168 Dukes' stage B colorectal carcinomas.

Methods-Allelic deletion at the p53 tumour suppressor gene locus was detected using polymerase chain reaction (PCR) based loss of heterozygosity (LOH) assays. Overexpressed proteins were detected using the CM1 polyclonal antibody. A PCR based assay was used to detect the presence of activating mutations at codon 12 of c-Ki-ras. Immunostaining was carried out using a monoclonal antibody to p21 ${ }^{\text {ras }}$.

Results-p53 LOH, CM1 immunostaining, c-Ki-ras mutational activation, and $\mathbf{p} 21^{\text {ras }}$ immunostaining were not predictive of survival by logrank analysis. Multivariate analysis using Cox regression did not predict survival in this group of tumours.

Conclusions-Aberrations in ras and p53 are unlikely to play an important role in the subdivision of patients with Dukes' stage $B$ colorectal carcinoma into more accurate prognostic strata. It is possible that later genetic events are more important in conferring a specific phenotype on the resultant Dukes' stage B tumour. (f Clin Pathol: Mol Pathol 1995;48:M310-M315)
\end{abstract}

Keywords: $p 53$, ras, Dukes' stage B colorectal carcinoma, survival.

Biochemistry,

Royal College of

Surgeons

in Ireland, Dublin,

Ireland

M A Bennett

D T Croke

Department of

Pathology

E W Kay

$M$ Leader

L O'Flaherty

Department of

Gastroenterology and

Gastroenter

St Vincent's Hospital,

Dublin, Ireland

H Mulcahy

D P O'Donoghue

Correspondence to:

Dr D T Croke,

Department of Biochemistry,

Royal College of Surgeons in

Ireland, 123 St Stephen's

Green, Dublin 2, Ireland.

Accepted for publication

13 July 1995

About one third of all colorectal tumours are designated Dukes' stage B. ${ }^{1}$ Although this group of tumours is homogeneous from a pathological point of view, it exhibits significant clinical heterogeneity as exemplified by the variation in five year survival rates $(50-78 \%)$ observed after surgery alone. ${ }^{12}$ While Dukes' staging is a proven prognostic indicator in colorectal carcinoma generally, ${ }^{34}$ there are no parameters available as yet which permit the subdivision of the patient cohort with Dukes' stage B cancer into more accurate prognostic strata. Such parameters would assist in targeting patients for adjuvant therapy. This study seeks to address this issue by means of a retrospective study of the prognostic relevance of ras and p53 aberrations in Dukes' stage B colorectal carcinoma.

Aberrations in many genes including the $p 53$ tumour suppressor gene and $\mathrm{c}-\mathrm{Ki}$-ras oncogene occur frequently in the genesis of colorectal tumours. ${ }^{56}$ In vitro, certain combinations of oncogenes co-operate to transform primary cells. One such combination is ras and $p 53 .^{78}$ Tumour cells harbouring activated ras and $p 53$ have a growth advantage and may be selected for during tumorigenesis in vivo. Such genetic changes may correlate with tumour progression and may be markers of outcome which would be of particular importance in the treatment and management of patients.

Deletion of alleles in tumours from individuals heterozygous for polymorphisms can be assessed using loss of heterozygosity $(\mathrm{LOH})$ assays. These assays depend on the presence of polymorphisms-for example, restriction fragment length polymorphisms (RFLPs), in the gene. Two such polymorphisms in the $p 53$ gene at sites for the restriction endonucleases $M s p \mathrm{I}$ and $A c c$ II have been identified. ${ }^{910}$ p53 protein aberrations can be assessed using immunohistochemistry which detects overexpressed protein. Such assays have been used extensively in the assessment of p53 abnormalities in colorectal carcinoma. ${ }^{11-15} \mathrm{Ac}$ tivation of the c-Ki-ras oncogene can be detected by polymerase chain reaction (PCR) based techniques capable of detecting single point mutations in the gene and by immunohistochemical techniques which detect overexpressed protein.

While some studies have shown ras and/or p53 aberrations to be of importance in the prediction of survival in colorectal carcinoma, ${ }^{1214-18}$ the relevance of these phenomena to survival prediction in Dukes' stage B colorectal carcinoma is still unresolved.

\section{Methods}

In-series Dukes' stage B colorectal carcinomas $(\mathrm{n}=168)$ resected at a single institution ( $\mathrm{St}$ Vincent's Hospital, Dublin) between 1983 and 1989 were studied. Follow up to December 1994 was available for all 168 patients. Pathological variables (including Dukes' staging, Jass staging and differentiation) were determined by a single histopathologist (EWK).

\section{STATISTICAL ANALYSES}

Descriptive statistics and $\chi^{2}$ analyses were carried out using Datadesk software (Data Description Inc., New York, USA). Kaplan-Meier survival curves were constructed and logrank and Cox regression analyses were carried out using Stata software (Stata Corp., Texas, 
Acc II site : CGCG

GAGGCTGCTCCCCCCGTGGCCCCTGCACCAGCAGCTCCT Al allele

GAGGCTGCTCCCCGCGTGGCCCCTGCACCAGCAGCTCCT A2 allele

Mismatch PCR primer creates Sma I site (CCCGGG) in the Al allele

GCCAGAGGCTGCTCCCCCCGTGGCCCCTGCACCAGCAGCTC

3'-CCCGGGGACGTGGTCGTCGAG-5'

Sma I site : CCCGGG

\section{GAGGCTGCTCCCCCCGGGGCCCCTGCACCAGCAGCTC B2 allele}

\section{GAGGCTGCTCCCCGCGGGGCCCCTGCACCAGCAGCTC B1 allele}

Figure 1 SmaI assay for detection of the AccII RFLP in the p53 gene. The 3' mismatched oligonucleotide PCR primer created a restriction site for SmaI in subjects not exhibiting the AccII restriction site. The PCR product used in the AccII assay was generated and used as the template for a second (nested) PCR reaction utilising the mismatch primer and the sense oligonucleotide from the first reaction. After amplification of the appropriate region and digestion of the PCR product with SmaI, two possible alleles were generated. The $B 1$ allele resulted in a single 122 base pair (bp) fragment and the $B 2$ allele resulted in two fragments of 104 and $18 \mathrm{bp}$. Heterozygous individuals exhibit both alleles in normal cells. However, tumour cells may lose one copy of the $\mathrm{p} 53$ gene and this can be visualised as the loss of one allele (either B1 or B2) from the tumour cells.

Thus, the phenomenon of loss of heterozygosity can be used to assess deletion at the gene locus.

USA). Cancer related death was taken as the end point for all survival analyses.

\section{EXTRACTION OF DNA FROM PARAFFIN WAX} EMBEDDED MATERIAL

Haematoxylin and eosin stained slides of paraffin wax embedded tissue were used in the selection of tumour material and non-tumour mucosa adjacent to colorectal tumours. Tumour material with more than $70 \%$ neoplastic cells was considered suitable for PCR based analysis and serial sections from the same blocks were used for immunohistochemical analysis. DNA was extracted from paraffin wax embedded tumour and non-tumour material using a boiling/proteinase $\mathrm{K}$ method. Briefly, three $20 \mu \mathrm{m}$ sections from a representative

Table 1 Oligonucleotides and reaction conditions used for generating PCR products harbouring RFLPs within the $\mathrm{p} 53$ gene

\begin{tabular}{|c|c|}
\hline Reaction conditions & Oligonucleotide \\
\hline $\begin{array}{l}M s p \mathrm{I} \\
20 \mathrm{pmol} \text { each } \\
35 \text { cycles: } 1.5 \mathrm{minu}\end{array}$ & $\begin{array}{l}\text { 5'-AGGTCTGGTTTGCAACTGGG-3' } \\
\text { 5'-GAGGTCAAATAAGCAGCAGG-3' }^{\prime} \text { inutes } 61^{\circ} \mathrm{C}, 1.5 \text { minutes } 72^{\circ} \mathrm{C}\end{array}$ \\
\hline $\begin{array}{l}A c c \text { II (first) } \\
10 \text { pmol each } \\
12 \text { cycles: } 2 \text { minute }\end{array}$ & $\begin{array}{l}\text { 5'-AATGGATGATTTGATGCTGTCCC-3' } \\
5^{\prime} \text {-CGTGCAAGTCACAGACTTGGC- } 3^{\prime} \\
\text { es } 62^{\circ} \mathrm{C} \text {, } 2 \text { minutes } 72^{\circ} \mathrm{C}\end{array}$ \\
\hline $\begin{array}{l}\text { AccII (second) } \\
20 \text { pmol each } \\
35 \text { cycles: } 2 \text { minute }\end{array}$ & $\begin{array}{l}\text { 5'-AATGGATGATTTGATGCTGTCCC-3' } \\
5^{\prime} \text {-GAGCTGCTGGTCCAGGGGCCC- } 3^{\prime} \\
\text { es } 64^{\circ} \mathrm{C}, 2 \text { minutes } 72^{\circ} \mathrm{C}\end{array}$ \\
\hline
\end{tabular}

block were placed in a sterile $1.5 \mathrm{ml}$ Eppendorf tube with $700 \mu \mathrm{l}$ lysis buffer $(50 \mathrm{mM}$ Tris, $\mathrm{pH}$ 8.5, $1 \mathrm{mM}$ EDTA, $0 \cdot 5 \%$ Tween 20 ), boiled for 10 minutes, incubated for 48 hours at $37^{\circ} \mathrm{C}$ with proteinase $\mathrm{K}(0.4 \mathrm{mg} / \mathrm{ml})$, and boiled to inactivate proteinase $\mathrm{K}$. PCR products were generated on at least three separate occasions from all DNA templates to ensure that consistent results were obtained and to eliminate the possibility of inadvertent contamination from adjacent tumour/non-tumour material.

ALLELIC DELETION AT THE $p 53$ TUMOUR SUPPRESSOR GENE LOCUS

The $M s p I$ restriction endonuclease identifies a biallelic RFLP in intron 6 of the $p 53$ gene $^{9}$ and the $A c c$ II restriction endonuclease identifies a biallelic RFLP within exon 4 of the $p 53$ gene. ${ }^{10}$ A novel $3^{\prime}$ mismatch PCR was designed, exploiting the $A c c$ II site and the more cost-effective restriction endonuclease $S m a I$ (fig 1). The oligonucleotide primers used and reaction conditions for the PCR assay are outlined in table 1. Otherwise, assessment of allelic deletion was as described previously. ${ }^{910}$ DNA from 20 individuals was assayed to confirm that the SmaI genotype reflects accurately the $A c c$ II genotype (data not shown). PCR dilution experiments were also carried out to verify that preferential allele amplification did not occur.

\section{C-KI-ras MUTATIONAL ACTIVATION}

The PCR assay used to detect the activating mutation at codon 12 of the c-Ki-ras oncogene was that of Haliassos et al. ${ }^{19}$ This technique is about $95 \%$ sensitive and can be expected to detect about $75 \%$ of all ras mutations in colorectal tumours. PCR products from non-

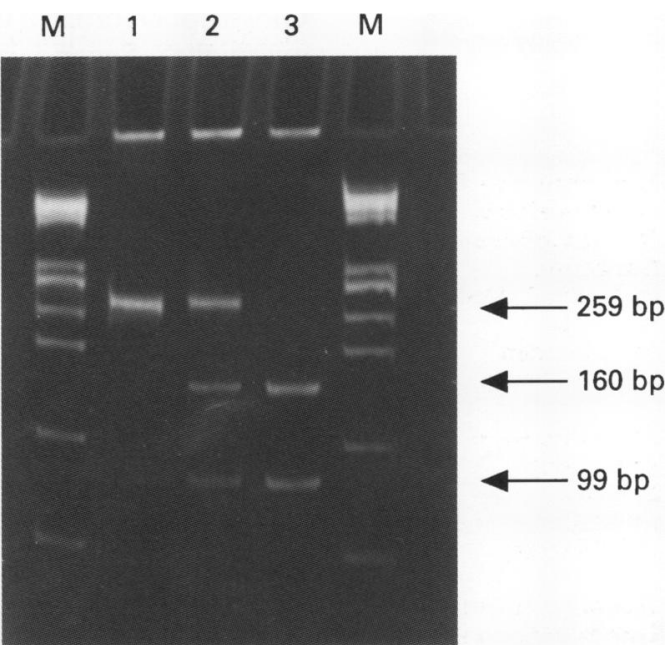

Figure 2 Allelic deletion at the $\mathrm{p} 53$ tumour suppressor gene locus. Ethidium bromide stained polyacrylamide gel showing (M) molecular weight marker (HaeIII digested $\Phi X 174$ DNA); lane 1, undigested PCR product harbouring the exon 4 AccII RFLP in the 53 tumour suppressor gene; lane 2, AccII digested PCR product suppressor gene; lane 2, AccII digested $P C R$ product with colorectal carcinoma (the $259 \mathrm{bp}$ fragment corresponds to one allele and the 160 and $99 \mathrm{bp}$ fragments correspond to the other allele); lane 3, digested PCR product from the colorectal tumour. The disappearance of the $259 \mathrm{bp}$ fragment is indicative of $\mathrm{LOH}$ or allelic the 259 bp fragment is indicative of $\mathrm{LOH}$ or allelic
deletion at the $\mathrm{p} 53$ tumour suppressor gene locus. 

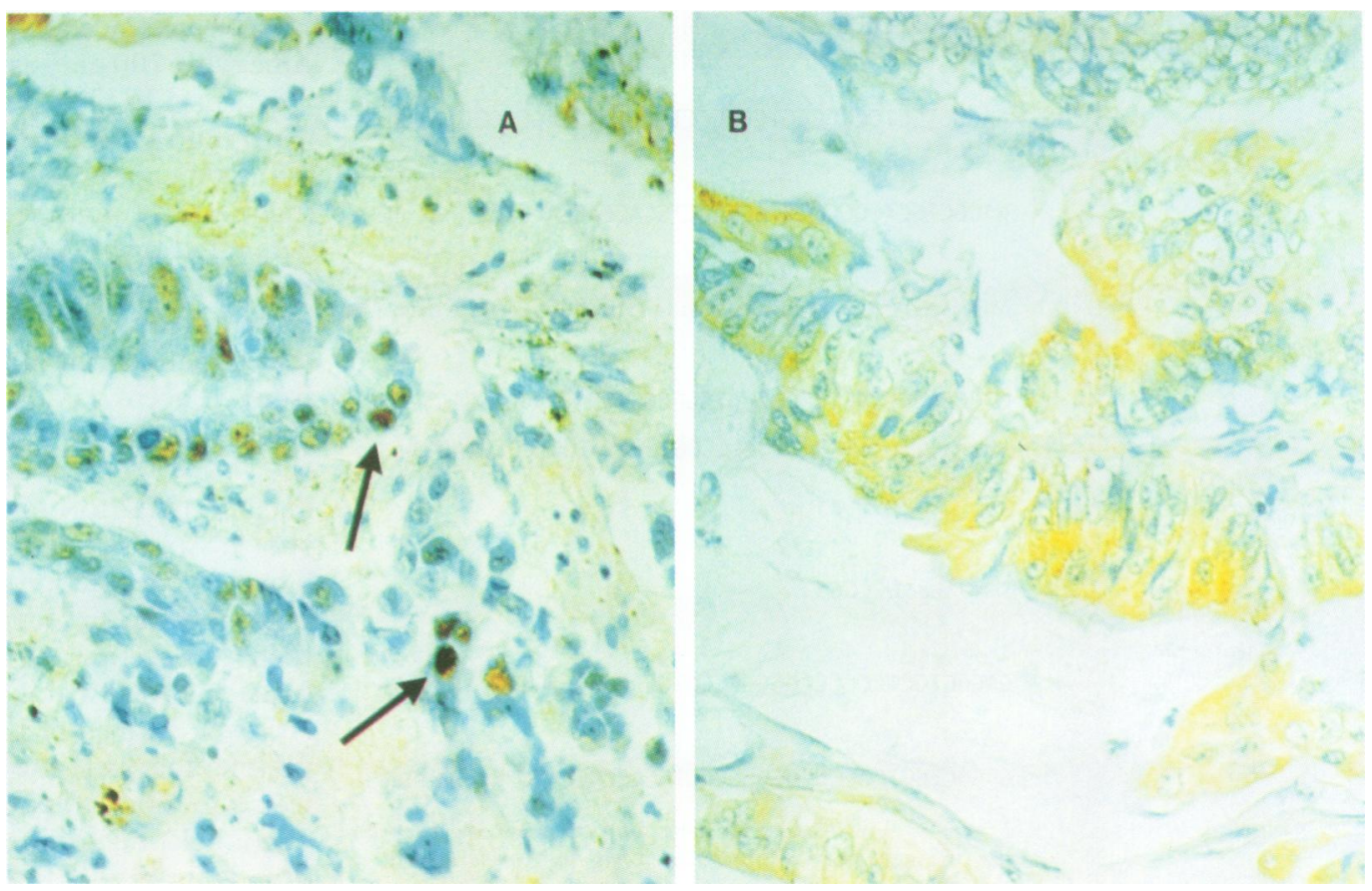

Figure 3 Colorectal tumours showing $(A)$ nuclear and $(B)$ cytoplasmic immunostaining detected with polyclonal antibody CM1.

tumour material and from five tumours shown by the PCR based assay to harbour an activating mutation were sequenced using the fmol DNA Sequencing System (Promega Corp., Wisconsin, USA) to confirm the validity of the assay.

\section{IMMUNOHISTOCHEMISTRY}

Five micron sections from 168 colorectal tumour blocks were dewaxed and rehydrated through graded alcohols. Primary antibody NCL-p53-CM1 (Novocastra, Newcastleupon-Tyne, UK.) or Dako-p21 $1^{\text {ras }}$ (Dako, Glostrup, Denmark) was applied and incubated overnight. Secondary antibody biotinylated swine anti-rabbit immunoglobulin or biotinylated rabbit anti-mouse immunoglobulin (Dako) was applied. Sections were then incubated with the avidin biotin peroxidase complex (Dako). Diaminobenzidine was used as

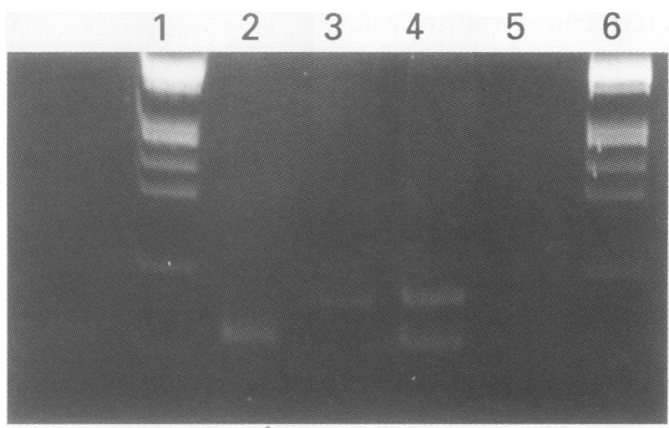

Figure 4 Ethidium bromide stained polyacrylamide gel showing (lanes 1 and 6) size marker (HaeIII digested $\Phi X 174 \mathrm{DNA})$; lane 2, MspI digested PCR product from non-tumour material ( $78 \mathrm{bp})$; lane $3, \mathrm{MspI}$ digested PCR product from cell line $S W 48$ exhibiting the activating mutation at both alleles (99 bp); lane 4, MspI digested $P C R$ product from tumour exhibiting the activating mutation at one allele ( 99 and 78 bp). Note: the 21 bp fragment is not shown. chromogen and haematoxylin as nuclear counterstain. Positive and negative control sections were included with each batch of tumours. Staining was scored as either positive or negative and the presence of nuclear and cytoplasmic staining was recorded.

\section{Results}

Allelic deletion at the $p 53$ tumour suppressor gene locus was observed in $34(40 \%)$ of 85 informative cases. Preferential allele amplification was not observed (data not shown). No bias was observed in the frequencies of allelic deletion observed at the two polymorphic loci examined in the $p 53$ gene. Six tumour samples previously shown to exhibit $p 53$ allelic deletion by Southern blotting were assayed using the RFLP based PCR method described above which confirmed the presence of allele loss in these tumours (data not shown). Figure

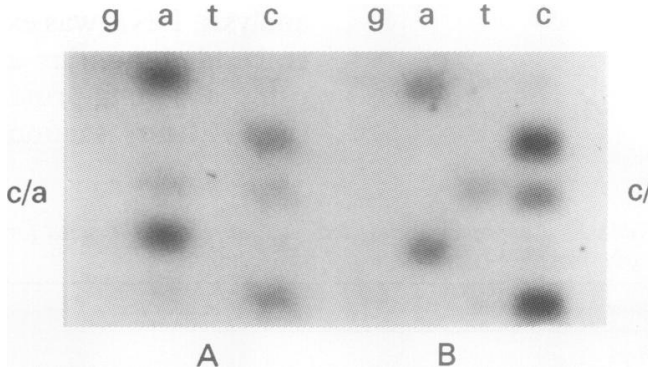

Figure 5 Nucleotide sequence of PCR products encompassing codon 12 of the c-Ki-ras oncogene from $(A)$ tumour sample found, using the PCR based assay, to harbour the activating mutation at codon 12 of the c-Kiras oncogene; tumour is heterozygous for an activating mutation ( $G$ to $T$ ) in the coding sequence of the $c-K i$-ras mutation ( $G$ to $T$ ) in the coding sequence of the $c-K i-$
oncogene. (B) Tumour sample found, using the PCR based assay, to harbour the activating mutation at codon 12 of the c-Ki-ras oncogene; tumour is heterozygous for an activating mutation ( $G$ to $A$ ) in the coding sequence of the $c-K i$-ras oncogene. 
Table $2 A$ Relation between codon $12 c$-Ki-ras mutation, $p 21^{\text {ras }}$ immunostaining and clinicopathological features in 168 patients with Dukes' stage $B$ colorectal carcinoma

\begin{tabular}{|c|c|c|c|c|c|c|}
\hline \multirow[b]{2}{*}{ Clinicopathological feature } & \multicolumn{3}{|c|}{$c-K i$-ras mutation } & \multicolumn{3}{|c|}{$p 21^{\text {ras }}$ immunostaining } \\
\hline & $\begin{array}{l}\text { Negative } \\
(n=112)\end{array}$ & $\begin{array}{l}\text { Positive } \\
(n=45)\end{array}$ & $p$ value & $\begin{array}{l}\text { Negative } \\
(n=89)\end{array}$ & $\begin{array}{l}\text { Positive } \\
(n=78)\end{array}$ & $p$ value \\
\hline $\begin{array}{l}\text { Age at diagnosis (years) } \\
\text { median (range) }\end{array}$ & $70 \cdot 5(44-90)$ & $68(41-87)$ & NS* & $70(43-90)$ & $68.5(41-87)$ & NS* \\
\hline $\begin{array}{l}\text { Sex } \\
\text { male } \\
\text { female }\end{array}$ & $\begin{array}{l}62 \\
50\end{array}$ & $\begin{array}{l}23 \\
22\end{array}$ & NSt & $\begin{array}{l}52 \\
37\end{array}$ & $\begin{array}{l}38 \\
40\end{array}$ & NSt \\
\hline $\begin{array}{l}\text { Tumour site } \\
\text { rectum } \\
\text { colon }\end{array}$ & $\begin{array}{l}29 \\
83\end{array}$ & $\begin{array}{l}22 \\
23\end{array}$ & $0.005 t$ & $\begin{array}{l}23 \\
66\end{array}$ & $\begin{array}{l}33 \\
45\end{array}$ & $0.024 \dagger$ \\
\hline Tumour size $(\mathrm{cm})$ mean $(\mathrm{SD})$ & $5 \cdot 4(2 \cdot 1)$ & $4 \cdot 7(2 \cdot 3)$ & $0 \cdot 049^{*}$ & $5 \cdot 4(2 \cdot 2)$ & $5 \cdot 1(2 \cdot 2)$ & NS* \\
\hline $\begin{array}{l}\text { Tumour differentiation } \\
\text { poor } \\
\text { moderate } \\
\text { well }\end{array}$ & $\begin{array}{r}11 \\
98 \\
3\end{array}$ & $\begin{array}{r}2 \\
40 \\
3\end{array}$ & NSt & $\begin{array}{r}4 \\
82 \\
3\end{array}$ & $\begin{array}{r}8 \\
67 \\
3\end{array}$ & NSt \\
\hline
\end{tabular}

* Student's $t$ test; $\nmid \chi^{2}$ test.

Table 2B Relation between p53 LOH, p53 immunostaining and clinicopathological features in 168 patients with Dukes' stage B colorectal carcinoma

\begin{tabular}{|c|c|c|c|c|c|c|}
\hline \multirow[b]{2}{*}{ Clinicopathological feature } & \multicolumn{3}{|l|}{ p53 LOH } & \multicolumn{3}{|c|}{ p53 immunostaining } \\
\hline & $\begin{array}{l}\text { Negative } \\
(n=51)\end{array}$ & $\begin{array}{l}\text { Positive } \\
(n=34)\end{array}$ & $p$ value & $\begin{array}{l}\text { Negative } \\
(n=46)\end{array}$ & $\begin{array}{l}\text { Positive } \\
(n=122)\end{array}$ & $p$ value \\
\hline $\begin{array}{l}\text { Age at diagnosis (years) } \\
\text { median (range) }\end{array}$ & $67(41-82)$ & $66(44-90)$ & NS* & $67(41-84)$ & $70(43-90)$ & NS* \\
\hline $\begin{array}{l}\text { Sex } \\
\text { male } \\
\text { female }\end{array}$ & $\begin{array}{l}25 \\
26\end{array}$ & $\begin{array}{l}18 \\
16\end{array}$ & NSt & $\begin{array}{l}23 \\
46\end{array}$ & $\begin{array}{l}67 \\
55\end{array}$ & NSt \\
\hline $\begin{array}{l}\text { Tumour site } \\
\text { rectum } \\
\text { colon }\end{array}$ & $\begin{array}{l}18 \\
33\end{array}$ & $\begin{array}{l}10 \\
24\end{array}$ & NSt & $\begin{array}{l}13 \\
33\end{array}$ & $\begin{array}{l}43 \\
79\end{array}$ & NSt \\
\hline Tumour size $(\mathrm{cm})$ mean $(\mathrm{SD})$ & $5 \cdot 2(2 \cdot 2)$ & $4 \cdot 8(1.9)$ & NS* & $5 \cdot 2(2 \cdot 1)$ & $5 \cdot 2(2 \cdot 3)$ & NS* \\
\hline $\begin{array}{l}\text { Tumour differentiation } \\
\text { poor } \\
\text { moderate } \\
\text { well }\end{array}$ & $\begin{array}{r}3 \\
46 \\
2\end{array}$ & $\begin{array}{r}2 \\
31 \\
1\end{array}$ & NSt & $\begin{array}{r}6 \\
38 \\
2\end{array}$ & $\begin{array}{r}7 \\
111 \\
4\end{array}$ & NSt \\
\hline
\end{tabular}

* Student's $t$ test; $+\chi^{2}$ test.

2 shows an example of $\mathrm{LOH}$ detected using the PCR based method.

Using the polyclonal antibody CM1, nuclear staining was assessed in 168 Dukes' stage B colorectal tumours. Nuclear staining was observed in $75(46 \%)$ of 168 and cytoplasmic staining in $112(67 \%)$ of 168 tumours. Interobserver variation in the determination of the presence, location and extent of p53 immunostaining using CM1 was very low. Forty colorectal tumours were selected randomly from this population and assessed independently by two pathologists; complete $(100 \%)$ concordance was observed in their findings. This was part of a larger study of 121 tumours of varying origin in which disagreement between observers for the assessment of p53 immunostaining occurred in just eight of the 121 cases (EWK, manuscript in preparation). Figure 3 shows nuclear and cytoplasmic immunostaining detected with CM1.

Figure 4 shows wild-type and mutant c-Kiras alleles. Normal mucosa from 40 individuals examined was negative for the activating mutation. Wild-type c-Ki-ras was observed in mucosa $2 \mathrm{~cm}$ from the tumour margin (data not shown). Activating mutation at codon 12 was observed in $45(40 \%)$ of 157 colorectal tumours. Figure 5 shows the sequence flanking codon 12 of the c-Ki-ras oncogene of two tumours, each exhibiting one wild-type allele and one mutant allele. p2 $1^{\text {ras }}$ immunostaining was detected in $78(47 \%)$ of 167 colorectal carcinomas.

The data were tested for associations between ras and p53 aberrations and a number of clinicopathological variables (table 2). Two significant associations were found; tumours which exhibited codon $12 \mathrm{c}-\mathrm{Ki}$-ras mutation were smaller than those which did not $(p=$ 0.049 ) and were more likely to be located in the rectum $(p=0 \cdot 005)$. This latter finding was also observed for $\mathrm{p} 21^{\text {ras }}$ immunostaining $(\mathrm{p}=$ 0.024).

Survival analysis of the 168 patients with Dukes' stage B colorectal carcinoma revealed that none of the clinicopathological variables, either singly or in combination, was capable of predicting survival. Kaplan-Meier survival curves for p53 LOH, p53 immunostaining, c$\mathrm{Ki}$-ras mutational activation and $\mathrm{p} 21^{\text {ras }} \mathrm{im}$ munostaining show that none of these parameters is predictive of survival (fig 6).

\section{Discussion}

One of the major difficulties complicating the management of Dukes' stage B colorectal car- 

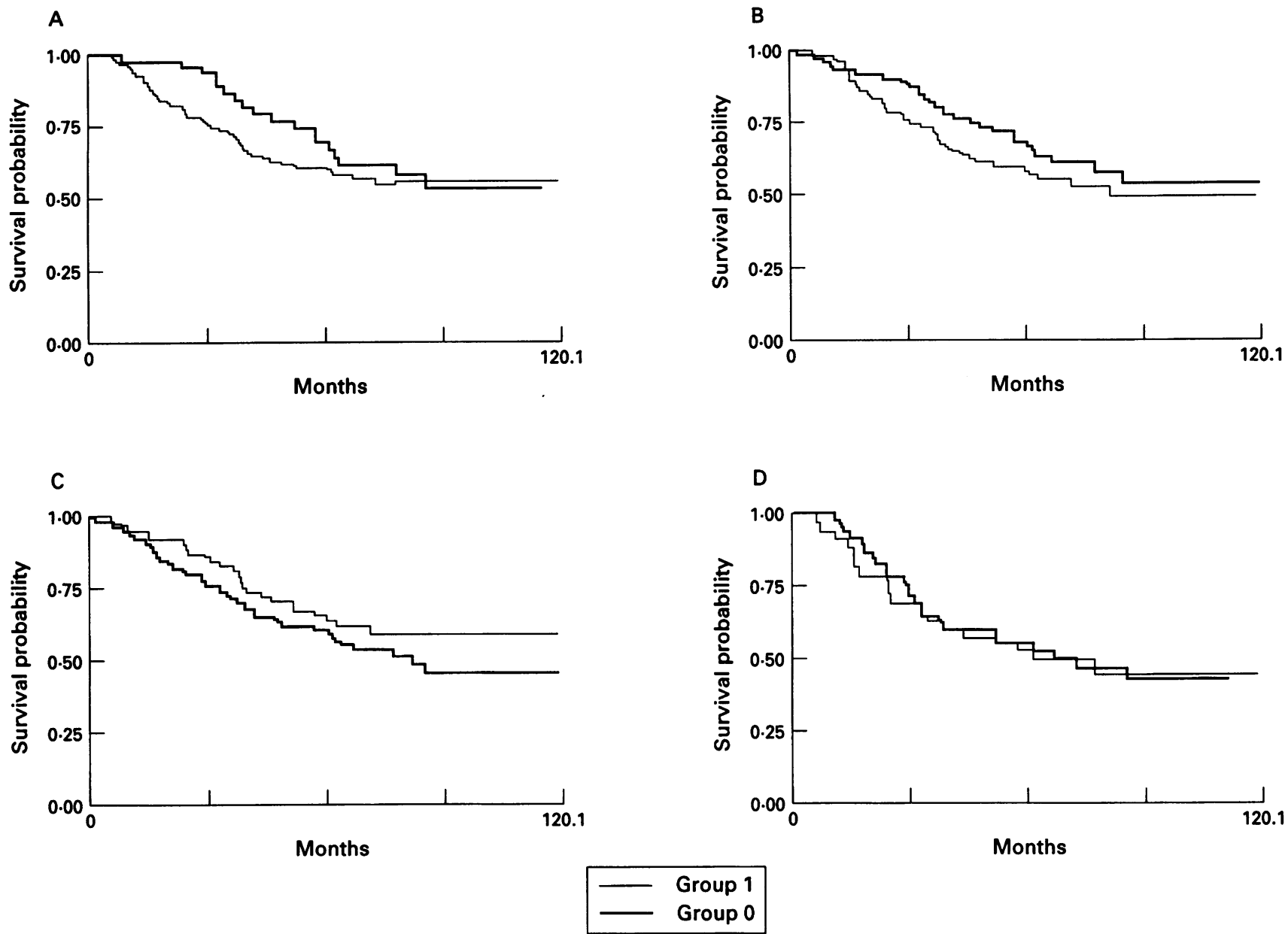

Figure 6 Kaplan-Meier survival curves for $(A) c$-Ki-ras mutation (logrank $p=0 \cdot 395)$, (B) $p 21^{\text {ras }}$ immunostaining (logrank $\left.p=0 \cdot 265\right)$, (C) $p 53$ immunostaining (logrank $p=0.244$ ), and (D) 53 LOH (logrank $p=0.687$ ). In each graph Group 0 and Group 1 refer to patient groups negative and positive, respectively, for the parameter specified.

cinoma is the clinical heterogeneity of this group of tumours. The elucidation of parameters capable of dividing the histologically homogeneous Dukes' stage B cancers into more accurate prognostic strata would be of particular importance. This study, based upon a large in-series group of Dukes' stage B colorectal tumours, addresses the specific question of whether ras and p53 aberrations have any value as prognostic parameters in this situation. In this regard, the study is distinct from a number of recent studies which have investigated these and other parameters in patients with colorectal carcinomas of mixed Dukes' stage. ${ }^{14-172021}$

$\mathrm{LOH}$ at the $p 53$ tumour suppressor locus was observed in $40 \%$ of the Dukes' stage B tumours studied. This value is lower than those reported in the literature-for example, frequencies of $\mathrm{LOH}$ of up to $83 \%$ have been observed in colorectal carcinoma. ${ }^{13}$ However, as most of the studies described to date do not distinguish between tumours on the basis of Dukes' stage, comparisons may not be valid. Considerable care must be exercised in $\mathrm{LOH}$ assays to guard against bias in the assessment of allelic deletion. In this study specimens containing $\geq 70 \%$ neoplastic tissue were used, assays were performed in triplicate and preferential amplification of alleles was not observed. It is possible that the frequency of $p 53$ allelic deletion increases with tumour progression. Indeed, distant metastases from colorectal tumours have been associated with $17 \mathrm{p}$ deletion. ${ }^{2021}$ The frequency of $p 53 \mathrm{LOH}$ observed here may reflect the relatively early position of the Dukes' stage B stage in the progression of colon cancer.

The patterns of p53 immunohistochemical staining we have observed are similar to those reported by others. ${ }^{11-15}$ Detection of the protein by immunohistochemistry may be indicative of the presence of a mutation in the gene, due to binding with viral proteins or a result of DNA damage. $^{22}$

In this study of Dukes' stage B colorectal carcinomas $29 \%$ of the tumours exhibited an oncogenic mutation at codon 12 of the $\mathrm{c}-\mathrm{Ki}-$ ras oncogene. This represents about $75 \%$ of all possible ras mutations in colorectal tumours and is not significantly different from that reported by other investigators for colon tumours, irrespective of stage. ${ }^{63-27}$ Mutational activation of the c-Ki-ras oncogene causes a conformational change and constitutive activation of the protein; its increased stability can then be detected immunohistochemically. It is also possible that the mutant protein is overexpressed as a result of amplification of the mutant allele. The monoclonal antibody used for immunohistochemical analysis detects all overexpressed forms of the protein (both mut- 
ant and wild-type), which may explain the higher incidence detected with immunohistochemistry compared with the PCR based assay. The observation of a higher frequency of c-Ki-ras mutation in rectal tumours may indicate site specificity of mutational activation of the oncogene. ${ }^{27}$

While other studies have indicated the importance of specific aberrations (including ras and/or p53) in predicting long term outcome following colorectal cancer resection, we found that these alterations were not closely related to survival in our group of patients with Dukes' stage B colorectal carcinoma. These tumours, which extend beyond the bowel wall without nodal metastases, are in a transition phase between locally invasive (Dukes' stage A) and metastatic (Dukes' stage C) disease and it may be that other features are more important in their progression than ras or p53 alterations. Indeed, we have found previously that protease production with subsequent destruction of local barriers to tumour spread is the most important prognostic indicator in this particular group of patients. ${ }^{28}$ Others have also found that features which indicate tumour migration through tissue planes, such as the presence of vascular invasion ${ }^{29}$ or the presence of immunohistochemically detected lymph node micrometastases, ${ }^{30}$ are important prognostic factors in those patients with Dukes' stage B cancer. Thus, while ras and $\mathrm{p} 53$ alterations seem to be potential prognostic indicators when all colorectal cancer stages are considered, it may be that a study of other genetic aberrations will provide more precise prognostic information.

This work was supported by grants from the Health Research Board of Ireland and the Royal College of Surgeons in Ireland.

1 Chapuis PH, Dent OF, Fisher R, Newland RC, Pheils MT Smyth E, et al. A multivariate analysis of clinical and pathological variables in prognosis after resection of large bowel cancer. $\operatorname{Br} \mathcal{F}$ Surg 1985;72:698-702.

2 Nauta R, Stablein DM, Holyoke D. Survival of patients with stage B2 colon carcinoma: The Gastrointestinal Tumour Study Group experience. Arch Surg 1989;124:180-2.

3 Crissman JD, Zarbo RJ, Ma CK, Visscher DW. Histopathologic parameters and DNA analysis in colorectal pathologic parameters and DNA 1989;24:103-47.

4 Deans GT, Parks TG, Rowlands BJ, Spence RAJ. Prognostic factors in colorectal cancer. Br ₹ Surg 1992;79:608-13.

5 Baker SJ, Fearon ER, Nigro JM, Hamilton SR, Preisinger AC, Jessup JM, et al. Chromosome 17 deletions and p53 gene mutations in colorectal carcinomas. Science 1989, 244:217-21.

6 Bos JL, Hamilton SR, Verlaan de Vries M, van Boom JH van der Eb AJ, Vogelstein B. Prevalence of ras gene mutations in human colorectal cancers. Nature 1987;327: 293-7.

7 Parada LF, Land H, Weinberg RA, Wolf D, Rotter V. Cooperation between genes encoding p53 tumour antigen and ras in cellular transformation. Nature 1984;312:64951 .
8 Hinds PW, Finlay CA, Quartin RS, Baker SJ, Fearon ER, Vogelstein B, et al. Mutant p53 DNA clones from human colon carcinomas cooperate with ras in transforming primary rat cells: a comparison of "hot spot" mutant phenotypes. Cell Growth Differ 1990;1:571-80.

9 McDaniel T, Carbone D, Takahashi T, Chumakov P, Chang EH, Pirollo KF, et al. The MspI polymorphism in intron 6 of p53 (TP53) detected by digestion of PCR products. Nucleic Acids Res 1991;19:4796.

10 de la Calle-Martin O, Fabregat V, Romero M, Soler J, Vives J, Yague J. AccII polymorphism of the p53 gene. Nucleic Acids Res 1990;18:4963.

11 Rodrigues NR, Rowan A, Smith MEF, Kerr IB, Bodmer WF, Gannon JV, et al. p53 mutations in colorectal cancer. Proc Natl Acad Sci USA 1990;87:7555-9.

12 Auvinen A, Isola J, Visakorpi T, Koivula T, Hakama M. Overexpression of p53 and long-term survival in colon carcinoma. Br $\mathcal{F}$ Cancer 1994;70:293-6.

13 Campo E, dela Calle-Martin O, Miquel R, Palacin A, Romero M, Fabregat V, et al. Loss of heterozygosity of the p53 gene and p53 protein expression in human colorectal carcinoma. Cancer Res 1991;51:436-42.

14 Sun X-F, Cartensen JM, Zhang H, Stal O, Wingren S, Hatschek T, et al. Prognostic significance of cytoplasmic p53 oncoprotein in colorectal carcinoma. Lancet 1992;34 1369-73.

15 Remvikos Y, Tominaga O, Hammel P, Laurent-Puig, P, Salmon RJ, Dutrillaux B, et al. Increased p53 content of colorectal tumours correlates with poor survival. $\mathrm{Br} f$ Cancer 1992;66:758-64.

16 Bell SM, Scott N, Cross D, Sager P, Lewis FA, Blair GE, et al. Prognostic value of $\mathrm{p} 53$ over-expression and c-Ki-ras gene mutations in colorectal carcinoma. Gastroenterology 1993;104:57-64.

17 Hamelin R Laurent-Puig P, Olschwang S, Jego N, Asselain $\mathrm{B}$, Remvikos Y, et al. Association of p53 mutations with short survival in colorectal cancer. Gastroenterology 1994; 106:42-8.

18 Finkelstein SD, Sayegh R, Christensen S, Swalsky PA. Genotypic classification of colorectal adenocarcinoma. Cancer 1993;71:3827-38.

19 Haliassos A, Chomel JC, Grandjouan S, Kruh J, Kaplan JC, Kitzis A. Detection of minority point mutations by modified PCR technique: a new approach for sensitive diagnosis of tumor progression markers. Nucleic Acids Res 1989;17:8093-9.

20 Kern SE, Fearon ER, Tersmette KWF, Enterline JP, Leppert $M$, Nakamura Y, et al. Clinical and pathological associations with allelic loss in colorectal carcinomas. $¥ A M A$ 1989;161:3099-103.

21 Khine K, Smith DR, Goh H-S. High frequency of allelic deletion on chromosome $17 \mathrm{p}$ in advanced colorectal can cer. Cancer 1994;73:28-35.

22 Lane DP. p53, guardian of the genome. Nature 1992;358 15-16.

23 Forrester K, Almoquera C, Hank K, Grizzle WE, Perucho $M$. Detection of high incidence of K-ras oncogenes during human colon carcinogenesis. Nature 1987;327:298-303.

24 Vogelstein B, Fearon ER, Hamilton SR, Kern SE, Preisinger AC, Leppert $M$, et al. Genetic alterations during colorectal AC, Leppert M, et al. Genetic alterations during colorectal
tumor development. $N$ Engl f Med 1988;319:525-32.

25 Burmer GC, Rabinovitch PS, Leob LA. Analysis of c-Kiras mutations in human colon carcinoma by cell sorting, polymerase chain reaction and DNA sequencing. Cancer Res 1989;49:2141-6.

26 Capella G, Cronaur-Mitra S, Peinado MA, Perucho M Frequency and spectrum of mutations at codon 12 and 13 of the c-Ki-ras gene in human tumours. Envinon Health Perspect 1991;93:1251-31.

27 Breivik J, Meling GI, Spurkland A, Rognum TO, Gaudernack G. K-ras mutation in colorectal cancer: relations to patient age, sex and tumour location. Br $\mathcal{F}$ Cancer 1994 ; to patient
69:367-71.

28 Mulcahy HE, Duffy MJ, Gibbons D, McCarthy P, Parfrey $\mathrm{N}$, O'Donoghue DP, Sheahan K. Urokinase-type plasminogen activator and outcome in Dukes' B colorectal cancer. Lancet 1994;344:583-4.

29 Krasna MJ, Flancbaum L, Cody RP, Shneibaum S, BenAri G. Vascular and neural invasion in colorectal cancer. Cancer 1988;61:1018-23.

30 Greenson JK, Isenhart CE, Rice R, Mojzisik C, Houchens $\mathrm{D}$, Martin EW Jr. Identification of occult micrometastases in pericolic lymph nodes of Dukes' B colorectal cancer patients using monoclonal antibodies against cytokeratin and CC49. Correlation with long-term survival. Cancer 1994;73:563-9. 